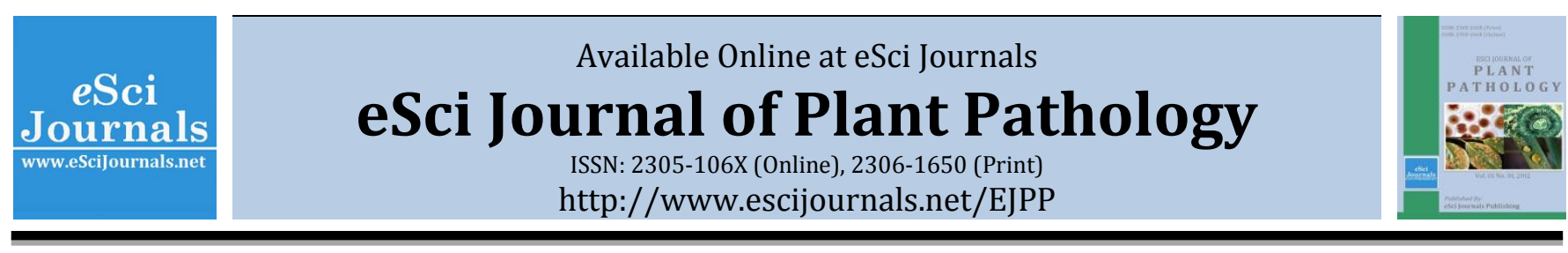

\title{
HISTOPATHOLOGICAL CHANGES AND ENZYMATIC ACTIVITIES INDUCED BY MELOIDOGYNE INCOGNITA ON RESISTANT AND SUSCEPTIBLE POTATO
}

\author{
aMahfouz M. M. Abd-Elgawad, bMarie-Claire Kerlan, cSergio Molinari, aFarid Abd-El-Kareem, dSanaa \\ S. A. Kabeil, aMoawad M. Mohamad, aWafaa A. El-Nagdi \\ a Plant Pathology Department, National Research Centre, Dokki 12622, Giza, Egypt. \\ b UMR INRA Agro Campus Rennes, Plant Breeding and Biotechnologies Vegetables, Kareiber, France. \\ c CNR, Istituto per la Protezione delle Piante, Sezione di Bari, Via G. Amendola 122/D, 70126 Bari, Italy. \\ c City for Scientific Researches and Technology Applications, Borg-Elarab, Alexandria, Egypt.
}

\section{A B S T R A C T}

All potato cultivars are susceptible to root-knot nematodes (Meloidogyne spp.) which infest the roots and induce galls on the surface and necrotic spots in the flesh tuber of potato, Solanum tuberosum. Infested tubers are unacceptable for processing and fresh market. Tubers are also putative source of dissemination of the nematode. A French nematode- resistant tetraploid potato genotype gained from ex-S. sparsipilum material hybridized with $S$. tuberosum in F1 and in their back cross progenies and designated as 02T.155.6 was tested and compared in the present study in Egypt as a suitable different environment. Histopathological changes and chitinase activity induced by M. incognita population, of common occurrence in Egypt, in four French tetraploid materials and two common cultivars known as nematode- resistant and susceptible potato genotypes were investigated. Hypertrophied cells were initiated in both cortical and steler regions of the roots which were then developed to abnormal xylem elements expanding into the cortex in French susceptible genotypes designated as 02T.149.6, 02T.150.54, and 02T.157.16. Nematode within the vascular tissue (stele) could induce giant cell development close to nematode heads. The largest number of such induced cells was shown by the cultivars Spunta and Diamant. The clone 02T.155.6 with putative nematode resistance demonstrated none or very little nematode development. Recently dead second stage juveniles could also indicate incompatible plant reaction to the invading nematodes in 02T.155.6. M. incognita, Giza population, resistance was generally more coherent to 02T.155.6 as demonstrated by our histological investigations but less coherent as shown by another Egyptian M. incognita population. Chitinase activity was enhanced in $M$. incognita (Giza)-inoculated with respect to uninoculated roots in all plants. After inoculation, such an activity generally increased more in roots of a potato genotype previously known to have resistance or relatively low numbers of both nematode galls and eggmasses than in the other tested cultivars. Peroxidase and catalase activities of nematode- inoculated with respect to uninoculated potato roots were presented and discussed.

Keywords: Enzymes, histopathological changes, Meloidogyne spp., nematode resistance, potato.

\section{INTRODUCTION}

Potato, Solanum tuberosum L., is a major food crop in 57 countries, which is more countries than any other single crop, with the exception of maize, and it is the only tuber crop produced in any significant amount in the developed countries (Scurrah et al., 2005). Hence, there is a need in many countries to improve the crop size and quality of potato because of the economic importance of the crop for local consumption and

* Corresponding Author:

Email: mahfouzian2000@yahoo.com

(C) 2012 eSci Journals Publishing. All rights reserved.

62 exportation to provide foreign exchange revenue. A key barrier to improvement of potato in Egypt (AbdElhak, 2005), Italy (Vovlas et al., 2005) and France (Berthou et al., 2003) is the reduction in yield and tuber quality caused by plant parasitic nematodes. For example, Shaltoot (2001) recorded $10 \%$ as potato yield losses due to damage by plant parasitic nematodes in Egypt. Successful potato production is dependent upon proper integration and usage of several cultural and pest management tools. Of special interests are the 
ongoing breeding programmes in France to improve the agronomic qualities and disease resistance of potato. All potato cultivars are susceptible to root-knot nematodes; Meloidogyne spp. (Kouassi et al., 2005). Nematode resistance, especially root-knot nematodes (RKN), ranks high among the several desireable plant characteristics for potato production in France (e.g., Berthou et al., 2003 and Kouassi et al., 2005) because there are four targets in breeding potato genotypes resistant to RKN: a) to grow acceptable potato crops without any nematode-galled tubers at harvest which reduce yield quality, b) to avoid RKN multiplication in galled roots since the latter represents a threat to the following crop, c) to prevent the nematode dissemination by galled tubers that can widen the nematode damage, and d) to ensure an environmentally safe potato production without chemical nematicides (Berthou et al., 2003). Also, potato cultivars carrying resistance to bacterial wilt (brown rot) caused by Ralstonia solanacearum lose their resistance when planted in Meloidogyne spp.-infested soil (Jatala, 1978).

In this respect, a French team (Berthou et al., 2003) has observed hypersensitive resistance to RKN in infested roots from ex-Solanum sparsipilum material hybridized with $S$. tuberosum in F1 and in their back cross F2 progeny. This resistance acts against Meloidogyne incognita, $M$. javanica and $M$. arenaria and their virulent isolates (These latter react against the gene, called Mi or $\mathrm{Mi}-1$, responsible for resistance in other plant species as tomato). These three nematode species represent the major root-knot nematode species in Egypt; we proposed to concentrate herein on the $M$. incognita dominant species in Egypt. This resistance protects the potatoes from galling on the roots and on the tubers. Like in the case of the Mi gene in tomato; this resistance decreases with high temperatures. Results from the F1 segregation confirm the hypothesis of a single dominant gene of potato (Kouassi et al., 2005). A pre-breeding program was carried out by the French team in order to transfer the resistance in advanced tetraploid progenies. The program aimed at cumulating several desirable traits such as agronomic measures and root-knot nematode resistance in tetraploid clones by UMR APBV-Potato team (Berthou et al., 2003 and Kouassi et al., 2005). Thereafter, advanced selected tetraploid materials have been created and their resistance has been confirmed for some clones in laboratory conditions in France. So, our primary interest was to test such genotypes for nematode resistance under Egyptian conditions especially high temperature. It was hypothesized (Kouassi et al., 2005) that the resistance is based on one dominant gene designated $\mathrm{Mh}$ and linked to the self-incompatibility locus-S. Hypersensitive plants should prevent nematode juveniles from feeding, developing and reproducing. The program produced genotypes and some of them were selected and have undergone preliminary tests for resistance in Egypt and France.

Hence, this work further examined histopathological changes as well as peroxidase, catalase and chitinase activity induced by Meloidogyne incognita population, of common occurrence in Egypt, in four French tetraploid materials known as nematode-resistant and susceptible potato genotypes as France and Egypt export potato to each other. Two susceptible cultivars widely grown in Egypt were included for comparison.

\section{MATERIALS AND METHODS}

Plant material: Nematode-resistance in infested roots from ex-S. sparsipilum material hybridized with $S$. tuberosum in F1 and in their back cross progenies were tested in France (Kouassi et al., 2005). Having successfully genotypically and phenotypically characterized resistance to root-knot nematode species, the French team proposed to experiment the newly resistant potato genotypes in Egypt as a suitable different environment. In addition to four tetraploid genotypes which were supplied by the French team and designated as 02T.149.6, 02T.150.54, 02T.155.6, and 02T.157.16 (Figure 1), two potato cultivars, i.e. Spunta And Diamant, commonly grown in Egypt and susceptible to $M$. incognita were compared with the French potato. The tubers were brought from Mixed Unit of Research, INRA AGRO Campus Rennes, Plant Breeding and Biotechnologies Vegetales, Keraïber, Ploudaniel, France to be experimented in Egypt. French investigations designated 02T.155.6 and 02T.154.13 as resistant and 02T.149.6, 02T.150.54, 02T.157.16 and 02T.153.8 as susceptible genotypes to $M$. incognita. Yet, due to insufficient amount of tubers and because of some rotted tubers and non-fully germinated eyes of six imported clones (Fig. 1), their planting was only for laboratory and greenhouse tests and clones designated as 02T.153.8 and 02T.154.13 were excluded from tests against Egyptian $M$. incognita $80 \mathrm{~km}$ population. 


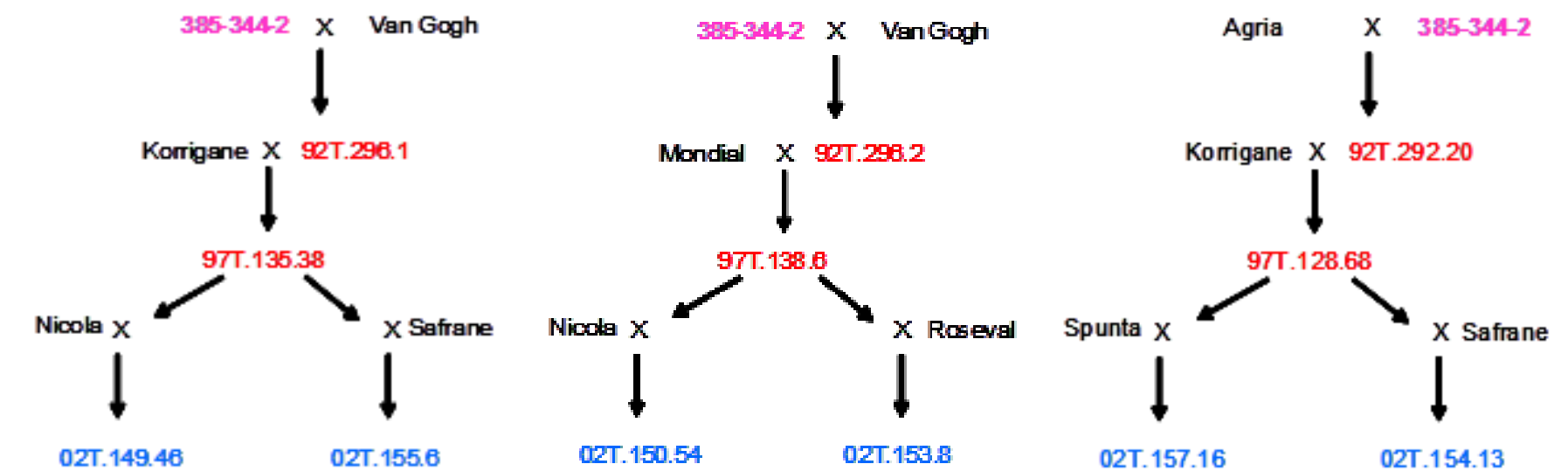

Figure.1. Genealogy of the material (blue color) tested. The resistant origin is the clone 385-344-2 provided by the CIP and has a multi-species origin. The red color indicates resistant genotypes which were obtained from this clone and used to produce the 6 clones $02 \mathrm{~T}$ brought to Egypt.

Nematode inoculum: Two Egyptian populations of $M$. incognita, known to grow and readily reproduce on potato and other susceptible vegetables planted at 80 $\mathrm{km}$ of Cairo-Alexandria desert road and Giza governorate; respectively, Egypt were used to infest the above-mentioned potato material by $M$. incognitasecond stage juveniles (J2) according to Molinari (2008).

Microscopic analysis of plant reactions to nematode infection: Tubers of the four tetraploid genotypes and two Solanum tuberosum cultivars were allowed to germinate in Petri dishes on agar at $25 \pm 2{ }^{\circ} \mathrm{C}$ as described by Mugniery and Person (1976). Two days after germination, each root-tip fwas inoculated with ten $M$. incognita Giza-second stage juveniles (J2). Two, 6 and 10 days after inoculation, $1 \mathrm{~cm}$ long pieces of roots were cut, fixed in formalin acetic acid (F. A. A.) alcohol solution and processed for histological technique according to the standard methods of Sass (1964). Dehydration was carried out in serial concentrations of known volumes of ethanol and butanol alcohols. Dehydrated root tissues were then infiltrated imbedded in paraffin wax at $25^{\circ} \mathrm{C}$ for 10 days. During the wax infiltration process, air bubbles were removed from root tissues by vacuum. Transverse and longitudinal sections of the processed root portions were made by a rotary microtom at 12 microns thickness. The sections were stained by saffranin and fast green. Sections were mounted in Canada balsam, and then examined under a light microscope (Daykin and Hussey, 1985). Photomicrographs were processed to clarify nematode penetration and development as related to cell structure to study the plant reaction to $M$. incognita invasion.
Preparation of crude extract for biochemical analyses: Tubers of the above-mentioned genotypes/cultivars were germinated in small $(3-\mathrm{cm}$ diameter) pots filled with sterilized peat and a single seedling per pot allowed to grow up to the four-trueleaf stage. Afterwards, seedlings were thoroughly washed with tap water and transplanted. Active second stage juveniles (J2) used for inoculation were obtained by incubation of RKN egg masses in tap water at $27{ }^{\circ} \mathrm{C}$ in the dark. J2 were collected every 2 days and concentrated in small volumes of sterilized water by filtering through 1 um filters (Whatman type) and collecting them after repeated washes (Molinari and Abd-Elgawad, 2007).

Seedlings were transplanted into $8-\mathrm{cm}$ diameter pots and at the same time were inoculated with 500 active second stage juveniles (J2) of $M$. incognita/seedling with twenty replicates (plants) for each genotype/cultivar, half of them were nematode inoculated. Enzymatic activities of peroxidase, catalase and chitinase (Table 1 and 2) were measured 12 days after the inoculation. Seedlings were harvested and roots were thoroughly rinsed with sterilized distilled water, excised from the plants, and separately dried and weighed. Then, roots were cut with scissors, placed in an ice-cold $0.05 \mathrm{M}$ phosphate buffer, $\mathrm{pH}$ 6.5, and ground by hand with a pestle in a porcelain mortar. This coarse homogenate was centrifuged under cooling conditions for $10 \mathrm{~min}$ at $10,000 \mathrm{x}$ g. The supernatants were recovered and the precipitates were re-extracted with the same buffer and re-centrifuged. The supernatants were pooled and designated as crude extracts (Mohamed et al., 1999). 
Peroxidase (EC 1.11.1.7) assay: Peroxidase activity was determined spectrophotometrically by measuring the increase in absorbency at $470 \mathrm{~nm}$ due to oxidation of guaiacol according to Lee (1973). One unit of enzyme activity was defined as the amount of enzyme that cause changes 1.0 O.D. min $^{-1}$ under standard assay conditions. Specific activity was expressed in units mg-1 protein.

Catalase (EC 1.11.1.6) assay: The enzyme activity of catalase was assayed by measuring the initial rate of hydrogen peroxide disappearance according to Chance and Maehly (1955). One unit of catalase activity was defined as the amount of enzyme which converts $1 \mu \mathrm{mol}$ of hydrogen peroxide $\mathrm{min}^{-1}$ under standard assay conditions. Specific activity was expressed in units mg-1 protein.

Protein determination: Protein was determined by the method of Bradford (1976) using bovine serum albumin as standard.

\section{Chitinase (EC 3.2.1.14) assay}

Preparation of colloidal chitin: The substrate colloidal chitin was prepared from chitin powder according to the method described by Ried and Ogryd-Ziak (1981). Twenty five grams of chitin was milled, suspended in $250 \mathrm{ml}$ of $85 \%$ phosphoric acid $\left(\mathrm{H}_{3} \mathrm{PO}_{4}\right)$ and stored at $4^{\circ} \mathrm{C}$ for $24 \mathrm{~h}$, then blended in 2 litre of distilled water using a warning blender and the suspension was centrifuged. This washing procedure was repeated twice. The colloidal chitin suspension in the final wash was adjusted to $\mathrm{pH} 7.0$ with $(1 \mathrm{~N}) \mathrm{NaOH}$, separated by centrifugation and the pelleted colloidal chitin was stored at $4^{\circ} \mathrm{C}$.

Determination of chitinase activity: Chitinase determination was carried out according to the method of Boller and Mauch (1988). Reducing sugar was determined in $1 \mathrm{ml}$ of the supernatant by dinitrosalicylic acid using $1 \mathrm{ml}$ of $1 \%$ colloidal chitin in $0.05 \mathrm{M}$ citrate phosphate buffer ( $\mathrm{pH}$ 6.6) in test tubes, $1 \mathrm{ml}$ of enzyme extract was added and mixed by shaking. One $\mathrm{ml}$ of $1 \%$ colloidal chitin in $0.05 \mathrm{M}$ citrate phosphate buffer $\mathrm{pH}$ 6.6) in test tubes, $1 \mathrm{ml}$ of crude extract was added and mixed by shaking. Tubes were kept in water bath at $37^{\circ} \mathrm{C}$ for 60 minutes, then cooled and centrifuged before assaying. Reducing sugar was determined in $1 \mathrm{ml}$ of the supernatant by dinitrosalicylic acid (Monreal and Reese, 1969). Optical density was determined at 540 $\mathrm{nm}$. Chitinase activity was expressed as $\mathrm{mM} \mathrm{N}$ acetylglucose amine equivalent released / gram fresh weight tissue/ 60 minutes.
Assessing effects of resistance on J2 development of M. incognita Giza: Three tubers of each of the six tetraploid genotypes in addition to Spunta and Diamant cultivars were individually placed in a $2 \mathrm{~cm}$ thick layer of moist sand in $150 \mathrm{~cm}^{3}$ perforated pots $(60 \times 70 \mathrm{~mm})$. After germination, each plant was inoculated with 1000 J2 of M. incognita population from Giza governorate.

Two days after inoculation, the pots were filled with organic substrate (organic matter 10\%; pH 7.0). The plants were arranged in the glasshouse in a completely randomized design and grown at about $25 \pm 2^{\circ} \mathrm{C}$ in day and $16 \pm 2{ }^{\circ} \mathrm{C}$ at night with regular watering. Six weeks after inoculation, the number of galls, egg masses and nematodes in the soils and roots were estimated. The part of the root system previously inoculated and growing in a sandy soil was removed and stained with acid fuchsine. Second-stage juveniles (J2), third- and fourth (J3 and J4, respectively), males and females of $M$. incognita were counted in each root system. Nematodes were extracted with a modified sieving and centrifugation technique (Grewal et al., 1997) from a $200 \mathrm{gm}$ portion of each pot identified and counted using a compound microscope.

Statistical analysis: Least significant difference test for multiple comparisons among means were utilized for analyzing differences among treatments concerning nematode developmental stages at the significance levels $\mathrm{P} \leq 0.05$ and 0.01 . Analysis of variance (ANOVA) was performed for the 3 variables (number of galls, number of eggmassses and number of nematodes in the soil and the roots) using SAS software. Duncan new Multiple range test was used for separation of treatment means for Enzyme bioassays (Duncan, 1955).

\section{RESULTS AND DISCUSSION:}

Histopathological changes: Stained root sections of the potato genotypes (four French tetraploid clones and two potato cultivars commonly grown in Egypt) were histologically examined under a stereoscopic microscope after different periods from $M$. incognita inoculation (Figures 2-4). The most obvious cell reactions to the nematode infection in the two potato cultivars, i.e. Spunta and Diamunt were cell hyperplasia and hypertrophy in comparison with uninfected portions of the roots. The hypertrophied cells were initiated in both cortical and steler regions of the roots which were then developed to abnormal xylem elements expanding into the cortex (Figure 2). Nematode within the vascular tissue (stele) could 
induce giant cell development close to nematode heads. The largest number of such induced giant cells was shown by those two cultivars, i.e. Spunta and Diamant, since they demonstrated higher numbers of root galls caused by the nematode than the other tested potato genotypes (Table 3). More nematode development occurred in the susceptible cultivars as the time lapsed after inoculation increased. Cross and longitudinal sections of the $M$. incognita-infected roots indicated that the French clone 02T.155.6 tested herein with putative nematode resistance was more coherent to $M$. incognita resistance than the other examined potato materials since this clone demonstrated none or very little nematode development (Figure 3). Recently dead second stage juveniles (Figure 3) could also indicate incompatible plant reaction to the invading nematodes. Moreover, in the putative resistant clone 02T.155.6 (Figures 3), the formation of such giant cells with nematode-feeding cells, as shown in the French susceptible tetraploid clone 02T.157.16 (Figures 4), was completely absent. On the contrary, in susceptible potato tubers, Vovlas et al. (2005) reported that $M$. javanica induced feeding sites that consisted of three to four hypertrophied giant cells per adult female and infection of feeder roots by the nematode resulted in mature large galls which usually contained at least one mature female and egg mass. They found that the feeding sites in both tubers and roots were characterized by giant cells containing granular cytoplasm and many hypertrophied nuclei with the cytoplasm in giant cells being aggregated alongside the thickened cell walls where stelar tissues within galls appeared disorganized.

Generally, the other French clones especially the genotype 02T 157.16 and 02T.150.54 displayed different developmental stages of $M$. incognita within root tissues which indicated similar or even more susceptibility to $M$. incognita than the cultivars Spunta and Diamant (Figures 2 and 4). The genotype 02T.150.54 has previously proved to be susceptible to M. incognita (D. Mugniery, personal communication) too but such nematode development in the roots of the remaining French clones 02T.149.46 and 02T.150.54 was not in the ideal structure formed in the highly susceptible plants. In the susceptible potato roots (Figures 2 and 4), Parenchyma type cells bordering the giant cells were small with dense protoplasm and irregular shape. The well-developed giant cells were generally filled with dense granulated cytoplasm, several nuclei and also had thickened cell walls. The number of nuclei per giant cell ranged from 2-7 which were scattered within the giant cell or aggregated in the center. Occasionally, some of the giant cells were vacuolated and abnormal xylem elements were scattered around giant cells. Also, a group of giant cells, forming a cluster, were usually located at the anterior part of the nematode especially for the susceptible cultivars Spunta and Diamant. The number of giant cells in a cluster ranged between 2 to 8 . The giant cells were irregular in shape; however, they tended to be elongated or rounded. Such histological observations were usually recorded by others (e.g., Eissa et al., 2003) but in roots of other $M$. incognita-susceptible plant species. Although hypersensitive resistance (HR) to root-knot nematodes was clearly observed in infested roots of tetraploid clones that have been tested previously by UMR APBV-Potato team (Berthou et al., 2003 and Kouassi et al., 2005), such HR observations were not so distinct in the histopathological changes induced by $M$. incognita infection reported herein (Figure 3), save for no induction of giant cells was observed, probably because the Egyptian nematode population is more virulent (Eddaoudi et al., 1997) and/or other stressing environmental factors have accounted for such variations since some J2 were active even after 10 days of inoculation.

Hypersensitive reaction in roots of potato resistant genotypes was characterized with cell necrosis encompassing the invading nematode juveniles but no necrosis occurred in compatible reaction where potato roots were susceptible to the nematode (Berthou et al., 2003 and Kouassi et al., 2005). In this respect, our investigation for such changes was carried out after the same periods reported by Kouassi et al. (2005); i.e. two, 6 and 10 days after nematode inoculation for HR genotypes (Figures 2 - 4). Furthermore, almost no females (0-3 on average per plant) were observed by Kouassi et al. (2005) whereas we recorded higher numbers of nematode galls per plant for the French susceptible tetraploid clones, e.g. an average of 13 nematode galls/plant for the genotype 02T 157.16 (Table 3 and Figure 4). Moreover, the average number of egg-masses on the roots of the four susceptible clones was in the range 6-10 compared to 20-22 eggmasses/root system for the standard highly susceptible Egyptian cultivars (Table 3). Numbers of eggmasses/root system should be more reliable than the number of nematode galls or even females because the 
number of eggs/egg-masses is necessary to determine the nematode fecundity on plant genotypes/cultivars in the breeding programs. In this respect, Meloidogyne incognita resistance was generally more coherent to the French clone with putative resistance as demonstrated by our histological investigations herein for the nematode population designated as $80 \mathrm{~km}$ but less
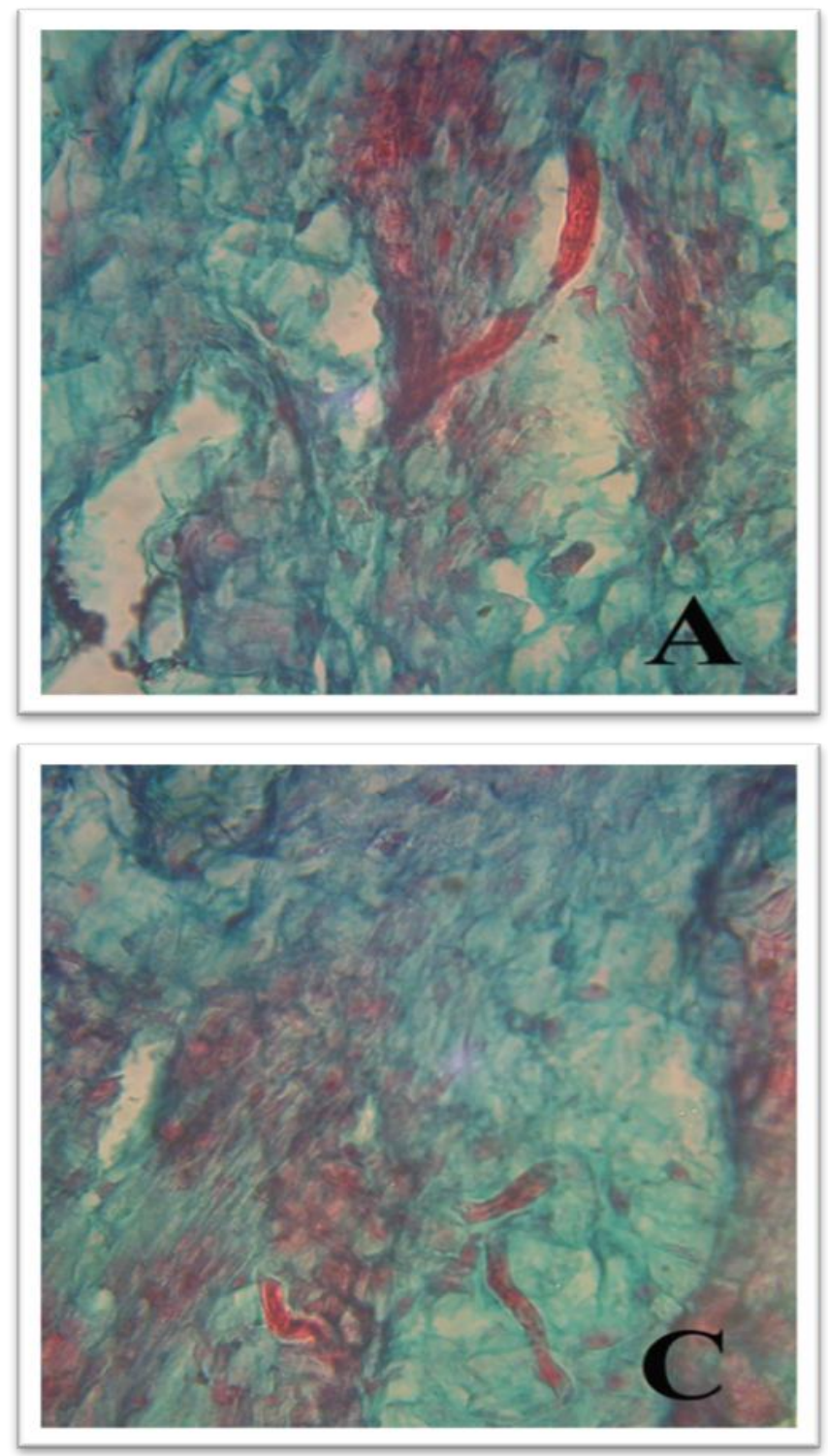

coherent as shown by Giza population. This latter was based on the numbers of nematode developmental stages within roots as well as their galls and egg masses in the greenhouse test (Table 3). This difference is possibly due to differences in the virulence of two geographically different Egyptian populations of $M$. incognita that were used for the same genotypes
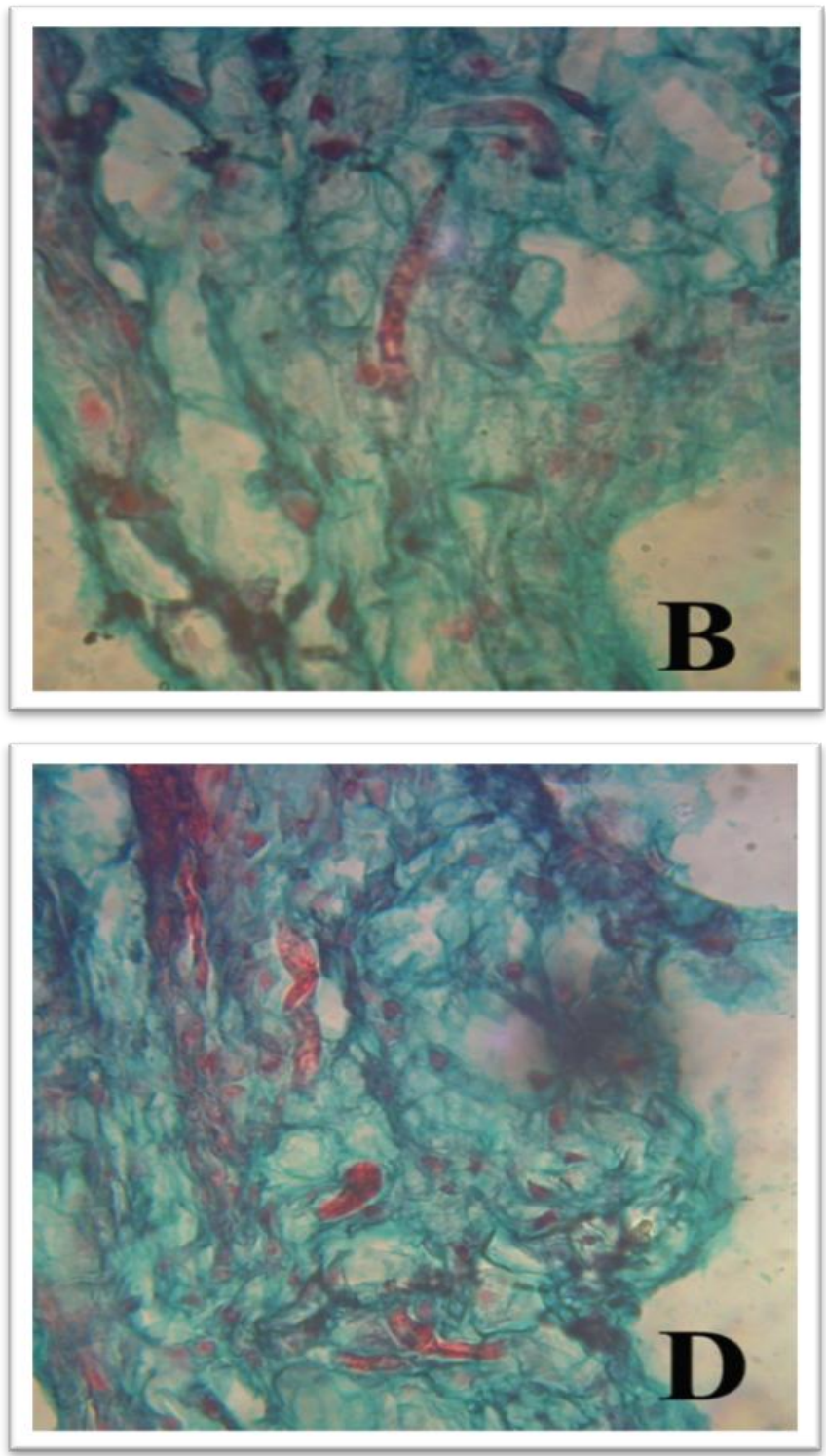

Figure. 2. Light micrograph of susceptible potato cultivar Spunta reaction to juveniles of Meloidogyne incognita (80 $\mathrm{km}$ population) penetration; ten days after nematode inoculation. A, B, C, and D. represents different recently formed giant cells as well as other developing nematode stages.

It is assumed that virulent nematode populations have an array of antioxidant enzymes more active than those of wild avirulent populations. This array may delay the defense reactions of resistant plants to virulent populations of nematode. So, the delay can be exploited by the invading nematode juveniles to secrete compounds which can trigger the transformation of plant cells into the feeding sites of nematodes (AbdElgawad and Molinari, 2008).

Chitinase Activity: Before nematode inoculation, this activity was higher $(\mathrm{P} \leq 0.05)$ in 02T.155.6, 02T.157.16 and 02T.149.6 than the others tested (Table 1). Such an 
activity was enhanced in nematode-inoculated with respect to uninoculated roots in all plants. More importantly, after the inoculation, such an activity was higher $(\mathrm{P} \leq$ 0.05) in 02T.155.6 and 02T.157.16 designated potato genotypes than in Spunta and Diamant cultivars. The former genotypes had relatively lower numbers of both root-knot nematode galls and eggmasses than the latter cultivars even with the other nematode population (Table 1). This coincides with the fact that chitinases, like other pathogensis-related (PR) proteins, play a role in plant resistance against distinct pathogens. The chitinases hydrolyze chitin which provides architectural reinforcement of biological structures such as fungal cell walls and nematode egg shells; these latter are involved in protection and selfdefense of nematodes. Also, transfer of the chitinase gene between different plant species has been successfully undertaken in an attempt to enhance the resistance of susceptible species to pathogenic fungi (Brogile et al., 1991). In plant roots infected with rootknot nematodes, genes with homology to several known plant defense genes including chitinase are induced locally within short time of inoculation (Williamson and Hussey, 1996) but systematically when invaded by $T$. harzianum (Yedidia et al., 1999). Defence gene transcription or enzyme activity is, most of the time, delayed and lower in compatible than in incompatible interactions which may explain results in table (1). Yet, in the putative resistant clone 02T.155.6, the increase in chitinase activity was only $22 \%$. It is probable that activation of some enzymes should be attributed to the substrate induction caused by plant- tissue degradation (Zinov'eva et al., 2001). Another possibility is their limited contribution to the immune response of the plant tissue. Further research should be carried out to understand the mechanisms by which induction of this enzyme occurs. Understanding the overview of chitinase will also provide a basis for improving the pathogenic activity of potential biocontrol strains, for developing novel biological control strategies and for exploring their roles in the plant defense (Sharma et al., 2011).

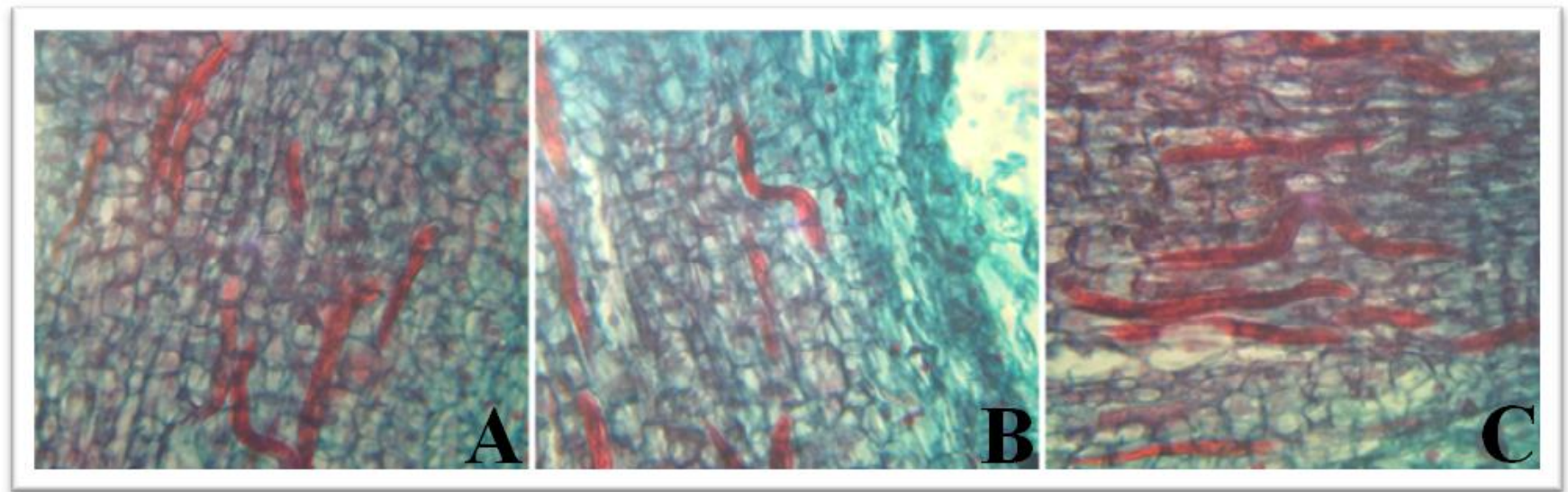

Figure 3. Light micrograph of potato tetraploid clone 02T-155.6 reaction to juveniles of Meloidogyne incognita penetration; ten days after nematode inoculation. A, B, and C show many invasions of nematodes but with dead or no nematode development.

Peroxidase activity. Such an activity was higher $(\mathrm{P} \leq$ 0.05), after nematode inoculation, in 02T.155.6, 02T.149.6 and 02T.157.16 designated potato genotypes than in 02T.150.54 genotype as well as Spunta and Diamant cultivars (Table 2). The former genotypes, reported herein with higher peroxidase activity (Table 2), had relatively lower numbers of both nematode galls and eggmasses than the latter ones (Table 3). Peroxidases play a major role in four physiological processes; auxin catabolism, defence mechanism against pathogens, some respiratory processes and synthesis of lignin as well as other terpenoids involved in phytoalexin production (Bashan et al., 1987). The activity of oxidative enzymes were tested in relation to nematode infection and proved to be useful as biochemical markers in various plant species such as tomato (e.g., Moliari, 1995 and Molinari and AbdElgawad, 2007).

Thus, these differences in enzyme activities from uninfected and infected potato roots might be used as fast and accurate biochemical markers for screening potato cultivars for $M$. incognita susceptibility/resistance. Further studies are needed to document their usefulness. 

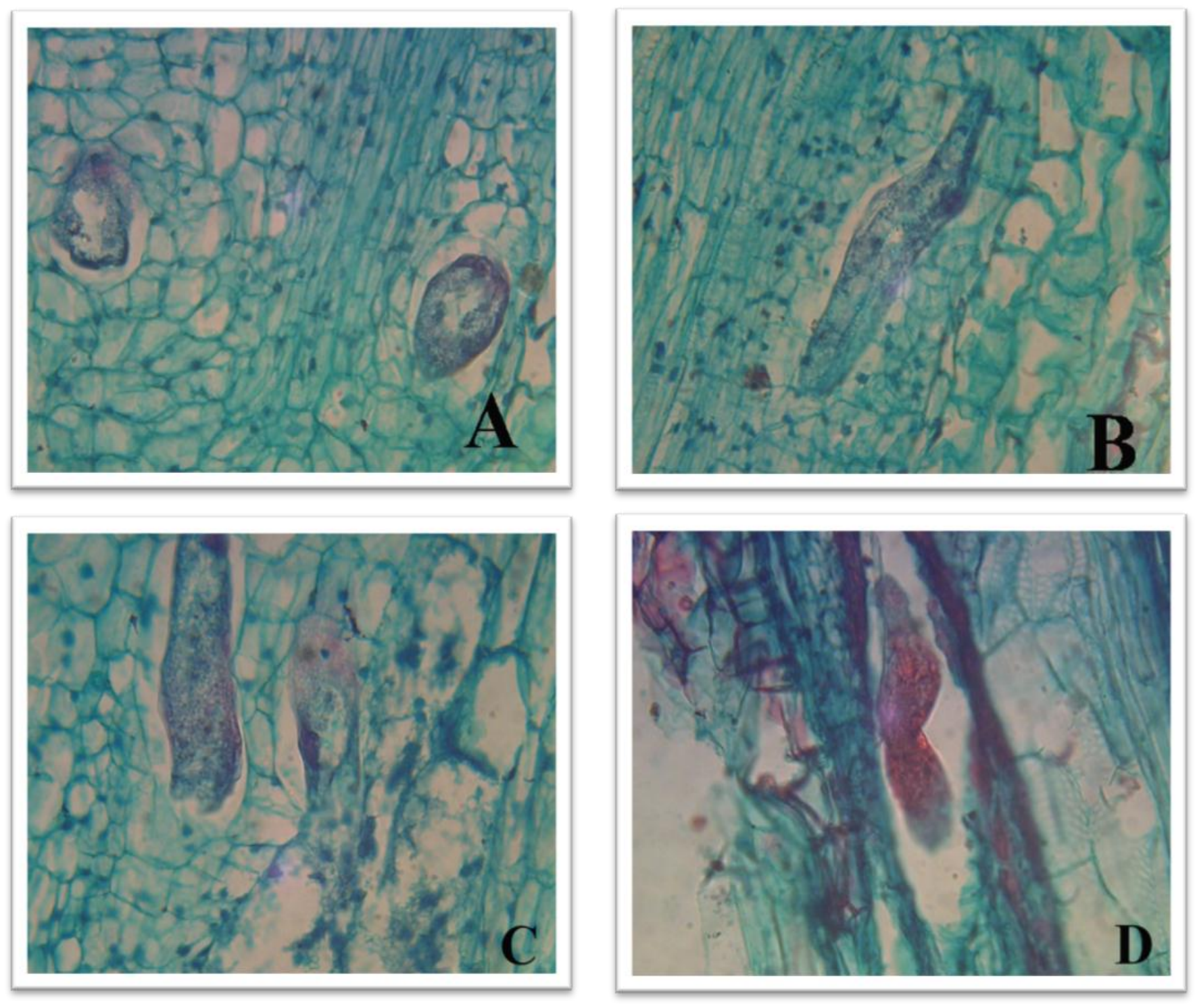

Figure 4. Light micrograph of potato tetraploid clone 02T.157.16 reaction to juveniles of Meloidogyne incognita penetration. A, B and C are six days after nematode inoculation. A. two different recently formed giant cells. B. Immature nematode female. C. A giant cell is formed around one of two developing nematode females, D. ten days after nematode inoculation.

Catalase activity: It is well known that Catalase catalyzes the decomposition of hydrogen peroxide to water and oxygen (Chelikani et al., 2004). It has one of the highest turnover numbers of all enzymes; one catalase molecule can convert 40 million molecules of hydrogen peroxide to water and oxygen each second (Goodsell, 2004). Catalase is usually located in a cellular organelle called the peroxisome (Alberts et al., 2002). Peroxisomes in plant cells are involved in photorespiration (the use of oxygen and production of carbon dioxide) and symbiotic nitrogen fixation (the breaking apart of diatomic nitrogen $\left(\mathrm{N}_{2}\right)$ to reactive nitrogen atoms). Hydrogen peroxide is used as a potent antimicrobial agent when cells are infected with a pathogen. Pathogens that are catalase-positive, such as Mycobacterium tuberculosis, Legionella pneumophila, and Campylobacter jejuni, make catalase in order to deactivate the peroxide radicals, thus allowing them to survive unharmed within the host (Srinivasa Rao et al., 2003). On the contrary, it is assumed that the host plant that have relatively much catalase will deactivate the peroxide radicals and thus enables the invading nematode, $M$. incognita, to survive unharmed within the host. 
Table (1). Chitinase activity of root extracts from potato plants. One set of seedlings was inoculated with Meloidogyne incognita (80km population) and another set was left uninfected as a control. Data refer to seedlings 12 days after inoculation.

\begin{tabular}{ccc}
\hline \multirow{2}{*}{ Cultivars/Genotypes $^{+}$} & \multicolumn{2}{c}{ Chitinase activity* $^{*}$} \\
\cline { 2 - 3 } & Non- inoculated & Inoculated $^{++}$ \\
\hline $02 T .155 .6$ & $9.0 \mathrm{a}$ & $11.0 \mathrm{a}$ \\
$02 \mathrm{~T} .150 .54$ & $6.4 \mathrm{~b}$ & $7.5 \mathrm{~b}$ \\
$02 \mathrm{~T} .157 .16$ & $9.4 \mathrm{a}$ & $12.4 \mathrm{a}$ \\
$02 \mathrm{~T} .149 .6$ & $8.0 \mathrm{a}$ & $10.0 \mathrm{ab}$ \\
Spunta & $6.0 \mathrm{~b}$ & $7.1 \mathrm{~b}$ \\
Diamant & $6.5 \mathrm{~b}$ & $8.0 \mathrm{~b}$ \\
\hline
\end{tabular}

Values are means of 10 replicates.

+The first four clones are tetraploid genotypes that have been supplied from French UMR APBV-Potato team while Spunta and Diamant are two Egyptian common cultivars.

++After ger $\urcorner$ mination, one-half of plants were inoculated with 500 second stage juveniles (J2) of M. incognita/plant.

*Chitinase activity was expressed as mM N-acetylglucose amine equivalent released / gram fresh weight tissue/ 60 minutes. Means in a column sharing a common letter are not significantly ( $\leq \leq 0.05)$ different according to Duncan's New Multiple Range Test.

Table (2). Peroxidase and catalase activities of root extracts from potato plants. One set of seedlings was inoculated with Meloidogyne incognita (80 km population) and another set was left uninfected as a control. Data refer to seedlings 12 days after inoculation.

\begin{tabular}{ccccc}
\hline \multirow{2}{*}{ Cultivars/Genotypes $^{+}$} & \multicolumn{2}{c}{ Peroxidase activity ${ }^{(\mathbf{1})}$} & \multicolumn{2}{c}{ Catalase activity $^{(2)}$} \\
\cline { 2 - 5 } & Non- inoculated & Inoculated $^{++}$ & Non-inoculated & Inoculated $^{++}$ \\
\hline $02 T .155 .6$ & $3.1 \mathrm{a}$ & $1.2 \mathrm{~b}$ & $2.2 \mathrm{~b}$ & $5.0 \mathrm{a}$ \\
02T.150.54 & $2.7 \mathrm{~b}$ & $1.1 \mathrm{~b}$ & $1.7 \mathrm{bc}$ & $4.5 \mathrm{~b}$ \\
02T.157.16 & $3.2 \mathrm{a}$ & $1.2 \mathrm{~b}$ & $1.5 \mathrm{c}$ & $5.2 \mathrm{a}$ \\
02T.149.6 & $3.0 \mathrm{a} \mathrm{b}$ & $1.3 \mathrm{~b}$ & $1.6 \mathrm{c}$ & $5.0 \mathrm{a}$ \\
Spunta & $3.2 \mathrm{~A}$ & $1.4 \mathrm{~b}$ & $2.5 \mathrm{a}$ & $2.3 \mathrm{c}$ \\
Diamant & $3.2 \mathrm{a}$ & $2.1 \mathrm{a}$ & $2.5 \mathrm{a}$ & $2.4 \mathrm{c}$
\end{tabular}

Values are means of 10 replicates, +The first four clones are tetraploid genotypes that have been supplied from French UMR APBV-Potato team while Spunta and Diamant are two Egyptian common cultivars.

++After germination, one-half of plants were inoculated with 500 second stage juveniles (J2) of Meloidogyne incognita/plant. (1) and (2) Peroxidase and catalase activities expressed as change in absorbance at 470 and $240 \mathrm{~nm}$; respectively. Means in a column sharing a common letter are not significantly $(\mathrm{P} \leq 0.05)$ different according to Duncan's New Multiple Range Test.

Such an assumption may be documented by the highest catalase level $(\mathrm{P} \leq 0.05)$ demonstrated by the susceptible Diamant cultivar (Table 2) since it demonstrated the highest numbers of both $M$. incognita galls and eggmasses (Table 3).

However, no significant difference was observed among other $M$. incognita infected potato genotypes reported herein to interpret catalase data based on the same assumption. Also, chitinase activities were higher in both putative resistant tetraploid clone, 02T.155.6, and the susceptible tetraploid clone 02T.157.16, in comparison with Spunta and Diamant cultivars. Such an increase in chitinase activity of 02T.157.16 and non-significant difference between the above-mentioned catalase data are probably because the mechanism for nematode resistance is complicated. So, examination of the histopathology, chitinase activity, peroxidase activity and catalase activity can only indirectly explain the scenario. Therefore, more experiments need to be conducted to reach sounder conclusion for using enzymes in screening potato cultivars for $M$. incognita susceptibility/resistance. 
Table (3). Effect of Meloidogyne incognita Giza on six French tetraploid resistant clones and two Egyptian common cultivars of potato plants grown under greenhouse conditions.

\begin{tabular}{lccc}
\hline $\begin{array}{l}\text { Clone designation or potato } \\
\text { cultivar* }\end{array}$ & No. Of galls & No. Of Egg-masses & $\begin{array}{c}\text { nematodes in soil } \\
\text { and roots+ }\end{array}$ \\
\hline INRA 02T.154.13 & 25 & 13 & 105 \\
INRA 02T.153.8 & 20 & 10 & 110 \\
INRA 02T.155.6 & 25 & 15 & 95 \\
INRA 02T.150.54 & 16 & 9 & 872 \\
INRA 02T.157.16 & 13 & 10 & 75 \\
INRA 02T.149.46 & 15 & 6 & 60 \\
Spunta & 30 & 20 & 130 \\
Diamant & 35 & 22 & 150 \\
L. S. D. at 5\% probability level & 7.52 & 6.12 & 11.29 \\
L. S. D. at 1\% probability level & 10.36 & 8.43 & 15.55 \\
\hline
\end{tabular}

Values are means of 3 replicates.

*The first six clones are tetraploid genotypes that have been supplied by French UMR APBV-Potato team while Spunta and Diamant are two Egyptian common cultivars.

For initial Meloidogyne incognita Population, after germination, each plant was inoculated with 1000 second stage juveniles (J2) of Meloidogyne incognita.

+Nematode-second stage juveniles (J2) in soil and plant roots as well as J3, J4 and adults in roots.

\section{ACKNOWLEDGEMENT}

This work has been carried out within the bilateral project "Technology transfer and innovation: Innovative technology for screening resistance against plant-parasitic nematodes of Solanaceae", based on an agreement for scientific and technological cooperation between the Foreign Ministry of Italy and the Egyptian Ministry of Scientific Research and an Egyptian-French mobility grant project no. IMHOTEP 35 entitled "Testing New French Potato Genotypes in Egypt for Nematode resistance".

\section{REFERENCES}

Abd-Elgawad M.M.M. and S. Molinari. 2008. Markers of plant resistance to nematodes: classical and molecular strategies. Nematol. medit. 36: 03-11.

Abd-Elhak, M.Z. 2005. Potato production and storage in Egypt (In Arabic). Egyptian Ministry of Agriculture:Issue no. 9 of The Horticulture Research Institute, Giza, Egypt.

Alberts, B., A. Johnson, J. Lewis, M. Raff, K. Roberts and P. Walter. 2002. Peroxisomes. Molecular Biology of the Cell (4th ed.). Garland Science, New York, USA.

Bashan, Y., Y. Okon, and Y. Henis. 1987. Peroxidase, polyphenol oxidase and phenol in relation to resistance against Pseudomonas syringae pv. Tomato in tomato plants. Canadian J. Bot. 65:366372.

Berthou, F., A. Kouassi, M. Bossis, J.P. Dante, M. Eddaoudi, Z. Ferji, R. Pelle, M. Taghzouti, D.
Ellisseche, D. Mugniery. 2003. Enhancing the resistance of the potato to tropical and mediterranean root-knot nematodes by using exSolanum sparsipilum germplasm. Euphytica 132: 57-65.

Boller, T. and F. Mauch, 1988. Colorimetric assay for chitinase. Methods Enzymol. 161: 430-435.

Bradford, M.M. 1976. A rapid and sensitive method for the quantitation of microgram quantities of protein utilizing the principle of protein-dye binding. Analyt. Biochemist. 72: 248-254.

Brogile, K., I. Chet, M. Holliday et al. 1991. Transgenic plants with enhanced resistance to the fungal pathogen Rhizotonia solani. Science 254:1194-1197.

Chance, B. and A.C. Maehly 1955. Assay of catalase and peroxidase. In: Methods in Enzymology, Vol. 2, pp. 764-775 (eds S.P. Colowick and N.O. Kaplan). Academic Press, New York, USA.

Chelikani, P., I. Fita, and P.C. Loewen. 2004. Diversity of structures and properties among catalases. Cell. Mol. Life Sci. 61 (2): 192-208.

Daykin, M.E. and R.S. Hussey. 1985. Staining and histopathological techniques in nematology. In :Barker, K. R.; Carter, C. C. and Sasser J. N.(eds). An advanced treatise on Meloidogyne. Raleigh, NC, North Carolina University Press, USA, , pp. 39-48.

Duncan, D.B. 1955. Multiple range and multiple F tests. Biometrics 11: 01-42.

Eddaoudi, M., M. Ammati and A. Rammah. 1997. Identification of resistance breaking populations of Meloidogyne on tomatoes and their effects on a 
new source of resistance. Funda. Appl. Nematol. 20: 285-289.

Eissa, M.F.M., A.Y. El-Gindi, M.M.M. Abd-Elgawad, A.E. Ismail and W.A. El-Nagdi. 2003. Histopathological changes induced by either root-knot or spiral nematodes on banana roots. Bull. NRC, Egypt 28 (4): 461-472.

Goodsell, D.S. 2004. Catalase. Molecule of the Month. RCSB Protein Data Bank. http://www.rcsb.org/pdb/static.do?p=education _discussion/molecule_of_the_month/pdb57_1.ht ml. Retrieved 2007-02-11.

Grewal, P.S., W.R. Martin, R.W. Miller and E.E. Lewis. 1997. Suppression of plant-parasitic nematode populations in turfgrass by application of entomopathogenic nematodes. Biocont. Sci. Tech. 7: 393-399.

Jatala, P.J. 1978. Studies on the interrelationships of the plant-parasitic nematodes and other organisms on potatoes. Pp.191-193 In: Report of the Second Nematode Planning Conference. International Potato Center, Lima, Peru.

Kouassi, A.B., M.C. Kerlan, M. Sobczac, J.P. Dantec,, C. Rouaux, D. Ellisseche, and D. Mugniery. 2005. Genetics and phenotypic characterisation of the hypersensitive resistance of Solanum sparsipilum to Meloidogyne incognita. Nematology 7(2): 213225.

Lee, T.T. 1973. On extraction and quantification of plant peroxidase isozymes. Physiol. Planta. 29:198-203.

Mohamed, M.A., M.M.A. Youssef and M.M.M. AbdElgawad. 1999. Measuring reaction of tomato cultivars to Meloidogyne incognita through appearance and enzyme activity. Int. J. Nematol. 9(2): 174-180.

Molinari, S. 1995. Difference in isoperoxidase activities of tomato roots susceptible and resistant to root-knot nematode. Nematologia Medit. 23:271-281.

Molinari, S. 2008. Bioassays on plant-nematode interactions. In: Plant Bioassays, Narwal S.S., Catalan C.A.N., Sampietro D.A., Vattuone M.A. and Politycka B. (Eds.). Science Publisher, Enfield, USA., pp. 293-326.

Molinari, S. and M.M.M. Abd-Elgawad 2007. Catalase inhibition as a biochemical marker of resistance to root-knot nematodes in tomato. Nematologia medit. 35: 237-242.

Monreal, J. and E.T. Reese. 1969. The chitinase of Serratia marcescens. Can. J. Microbiol. 15: 689696.
Mugniery, D. and F. Person 1976. Methodes d'elevage de quelques nematodes a kyste du genre Heterodera. Sci. Agron. 2217-2220.

Ried, J.D. and D.M. Ogryd-Ziak. 1981. Chitinase over producing mutant of Serratia marcescens. Appl. Environ. Microbiol. 41: 664- 669.

Sass J.E. 1964. Biotanical Microtechnique. The Iowa State University Press, 228 P.

Scurrah, M.I., B. Niere and J. Bridge. 2005. Nematode Parasites of Solanum and Sweet Potatoes. In: Luc, M., Sikora, R.A., and Bridge, J. (Eds). Plant Parasitic Nematodes in Subtropical and Tropical Agriculture, $2^{\text {nd }}$ edition: Wallingford, CABI Publishing, U. K. pp. 193-219.

Shaltoot, A. 2001. Economic loss resulting from nematode-infected vegetables and fruits. Proceedings of a workshop (In Arabic), Menoufia, Egypt. Disease problems caused by nematodes in horticultural farms in Egypt, 43-50.

Sharma, N., K.P. Sharma, R.K. Gaur and V.K. Gupta, 2011. Role of chitinase in plant defense. Asian J. Biochem. 6: 29-37.

Srinivasa Rao, P.S., Y. Yamada, K.Y. Leung. 2003. A major catalase (KatB) that is required for resistance to $\mathrm{H}_{2} \mathrm{O}_{2}$ and phagocyte-mediated killing in Edwardsiella tarda. Microbiology (Reading, Engl.) 149 (Pt 9): 2635-2644. doi:10.1099/mic.0.26478-0.

Vovlas, N., D. Mifsud, B.B. Landa and P. Castillo. 2005. Pathogenicity of the root-knot nematode Meloidogyne javanica on potato. Plant Pathol. 54: 657-664.

Williamson, V.M. and R.S. Hussey. 1996. Nematode pathogensis and resistance in plants. Plant Cell 8:1735-1745.

Yedidia, I., N. Benhamou and I. Chet. 1999. Induction of defense response in cucumber plants (Cucumis sativus L.) by the biocontrol agent Trichoderma harzianum. Appl. Environ. Microbiol. 65:10611070.

Zinov'eva, S.V., E.A. Perekhod, A.V. Il'ina, Zh. V. Udalova, N.G. Gerasimova, N.I. Vasyukova, O.I. Ozeretskovskaya and M.D. Sonin 2001. PR proteins in plants infested with the root-knot nematode Meloidogyne incognita (Kofoid and White, 1912) Chitwood, 1949. Doklady Biol. Sci. 379: 393-395. 